\title{
Osmanlı İmparatorluğunda Ermeniler: Osmanlı Türkçesi Ille Eserler Yazan Ermeni Entelektüeller (1800-1923)
}

\section{Yıldız DEVECi BOZKUŞ*}

\begin{abstract}
ÖZ
Bu çalışmada genel hatlarıla Osmanlı İmparatorluğu'nda 1800 ile 1923 yılları arasında yaşamış ve Osmanlı Türkçesi ile eserler kaleme almış olan Ermeni entelektüellerin hayatı ve eserleri incelenmiştir. Çalı̧̧ma kapsamında öncelikle Ermeni modernleşme sürecinde Ermeni entelijansiyanın oluşumundaki faktörlere yer verilmiştir. Bu çerçevede ilk etapta Ermeni modernleşme sürecine dair bazı bilgilere yer verilerek ardından XIX. Yüzyılda Ermeni entelijansiya kapsamında hangi isimlerin ön planda olduğu üzerinde durulmuştur. Söz konusu entelektüellerin hangi alanlarda eserler ürettikleri hakkında bilgi verilmiştir. Daha sonra özellikle Osmanlı Türkçesi kullanarak hangi alanlarda Ermeni entelektüellerinin eserler ürettikleri ve bu eserlerin söz konusu dönem içerisindeki yeri incelenmiştir. Osmanlı Türkçesi ile eserler kaleme alan Ermeni entelektüellerin hayat1, eserleri ve Osmanlı modernleşmesindeki rolüne de dikkat çekilerek bu eserlerin söz konusu dönemde hangi alanlarda kullanıldığ 1 ve toplum üzerindeki etkileri hakkında da bilgi verilmiştir. Makale kapsamında ilk etapta Osmanlı İmparatorluğu'nda Ermeni entelektüel dünyasını şekillendiren unsurlar tespit edilmiştir. Daha sonra Ermeni entelektüel dünyasının oluşumunda Tanzimat ve Islahat döneminin etkilerine yer verilerek, tıp, ekonomi, hukuk, tiyatro, eğitim, ziraat, filoloji, muhasebe konularında yurtdışnda eğitim alan Ermeni öğrencilerin kimler olduğu üzerinde durulmuştur. Bu alanlarda kimlerin ön plana çıktı̆̆ bilgilerine de yer verilerek özellikle bu alanlarda üretilen eserlerin toplumdaki yeri ve etkilerine dikkat çekilmiştir. Bu eserlerin hangi Osmanlı eğitim
\end{abstract}

Bu makaleye temel oluşturan araştırma 2019 yll TÜBİTAK 2219-Yurt Dışı Doktora Sonrası Araştırma Burs Programı kapsamında gerçekleştirilmiştir. TÜBİTAK'a desteği için teşekkür ederiz.

** Doç. Dr., Ankara Yıllııım Beyazıt Üniversitesi, İnsan ve Toplum Bilimleri Fakültesi, Ermeni Dili ve Edebiyatı Anabilim Dalı, Ankara/Türkiye

E-posta:yildizdeveci@gmail.com, ORCID: 0000-0002-4634-463X,DOI: 10.32704/erdem.838432 Makale Gönderim Tarihi: 13.03.2020 * Makale Kabul Tarihi: 22.07.2020 * (Araştırma Mk.) 
kurumlarında kullanıldıkları ve günümüzdeki önemine dair bilgilere de yer veren bu çalışmayla birlikte Osmanlı İmparatorluğu'nda Ermeni entelektüellerinin sadece sosyal bilimler alanında değil mühendislik, mimarlık, tıp, hukuk, ziraat vb. alanlarda da eserler kaleme aldıkları ve bu eserlerin toplumun modernleşme sürecindeki etkileri anlaş1lmaya çalışılmıştır. Bu çalışmada genel hatlarıyla çok fazla gün yüzüne çıkmamış olan Ermeni münevverlerinin kaleme almış olduğu eserlere de yer verilecektir. Böylece Ermenilerin Batılı kaynaklardan Osmanlı Türkçesine çevirdikleri eserler aracılığıyla devletin modernleşme ve batılılaşma yolunda atmış oldukları adımlarda nasıl bir rol oynadıkları hususuna açıklık getirilmeye çalışılmaktadır. Bu çalışma ayrıca Osmanlı İmparatorluğu döneminde yaşayan gayrimüslimlerin devlete olan aidiyetlerinin entelektüel seviyedeki konumunu göstermesi açısından da önemlidir. Makalede ayrıca söz konusu dönemde imparatorluk sınırları içerisinde yaşayan Ermenilerin büyük bir kısmının yurtdışından aldıkları eğitimler neticesinde elde etmiş oldukları bilgi ve birikimleri ülkeye döndüklerinde nasıl toplumun hemen hemen tüm alanlarına gerek çeviri gerekse telif eserler kaleme alarak yaydıklarına da açıklık getirmeye çalışmaktadır. Bu birikimin hem dönemin Türk ve Ermeni entelektüelleri hem de iki toplumun genç kuşakları üzerindeki etkilerine de dikkat çekilecektir.

Anahtar Kelimeler: Osmanlı İmparatorluğu,Ermeniler, modernleşme, entelijansiya, Osmanlı Türkçesi. 


\title{
Armenians in The Ottoman Empire: Armenian Intellectuals Who Wrote Ottoman Works (1800-1923)
}

\begin{abstract}
In this study, the life and works of Armenian intellectuals who lived in the Ottoman Empire between 1800 and 1923 and wrote Ottoman works will be emphasized. In the process of Armenian modernization, what are the factors in the formation of the Armenian intelligentsia will be given. In this framework, some information about the Armenian modernization process will be given in the first place, then XIX. The names of the Armenian intelligentsia will be emphasized in the 19th century. Information will also be given on the fields in which the intellectuals mentioned produce works. Then, especially in which areas the Armenian intellectuals produced works using Ottoman Turkish and the place of these works in that period will be emphasized. Attention will also be given to the life of the Armenian intellectuals, their works and their role in Ottoman modernization. Within the scope of the article, the elements that shape the Armenian intellectual world in the Ottoman Empire will be emphasized in the first place. Then, the effects of the Tanzimat and Islahat Reforms will be included in the formation of the Armenian intellectual world. It will be emphasized who are the Armenian students studying abroad in medicine, economy, law, theater, education, literature, agriculture, philology, press, and accounting. It will be emphasized who are the Armenian students studying abroad in medicine, economy, law, theater, education, literature, agriculture, philology, press, and accounting. Information on who comes to the fore in these areas will also be included. In particular, the place and effects of the works produced in these areas will be emphasized. Information on which Ottoman educational institutions these works were used and their importance today will also be included. The role of Armenians in the steps taken by the state towards modernization and westernization will also be clarified through the works translated from Western sources into Ottoman Turkish. It is also important in terms of showing the intellectual level of non-Muslims' belonging to the state. It also tries to clarify how the majority of Armenians, as a result of the education they received from abroad, spread the knowledge and experience they have acquired when they return to the country by writing translation and copyrighted works.
\end{abstract}

Keywords: Ottoman Empire, Armenians, modernization, intellectual, Ottoman Turkish. 


\section{Giriş}

O smanl İmparatorluğu'nda Ermeni entelektüellerinin hayatı ve eserlerine dair kapsamlı bilgiler içeren eserler arasında Kevork Pamukciyan'ın 4 ciltlik eserinin ilk sırada yer aldığını söylemek mümkündür. Pamukciyan'ın bu eseri dışında bu konularla ilgili olarak Ermeni aydınlarının hayatını ve eserlerini ele alan bir diğer çalışma ise Osmanlı İmparatorluğu döneminde Hariciye'de görev alan Ermenileri detaylı bir şekilde ele alan Taceddin Kayaoğlu'nun Osmanlı Hâriciyesinde Gayr-ı Müslimler (1852-1925) adlı eserdir. Hâriciye Nezareti Sicill-i Abvâl İdâresi Analitik Envanterinden yararlanılarak hazırlanan bu eser gayrimüslim memurlara dair son derece önemli bilgileri içermektedir. Bu eserde Ermeni memurlarının hizmet cetvelleri, emekliye ayrılma tarihleri, nüfus tezkireleri, Osmanlı ve yabancı devletler tarafindan verilen nişanlara ait berat suretleri ve diploma örnekleri gibi çok sayıda bilgilere yer verildiği görülmektedir. Yine Pars Tuğlacı'nın 4 cilt olarak kaleme almış olduğu Tarih Boyunca Batı Ermenileri adlı eser de bu konuyla ilgili detaylı bilgilerin yer aldığı nadir eserlerdendir. Tuğlacı'nın özellikle dördüncü cildinde Ermeni münevverlerin isimlerine ve eserlerine dair önemli bilgiler yer almaktadır (Tuğlacı, 2004).

Ermeni entelektüellerinin tarihi geçmişini Mesrop Maştots ile başlatan araştırmacılara göre 5. yüzyılda Mesrop Maştots ve müritleri, Kutsal Kitabı Ermeniceye çevirmek için Bizans'a gitmişlerdir (Hovannisian \& Payaslian, 2005:50-51). Kılıç’a göre Ermeni Kilisesi, ülkenin Batı bölgelerinde tamamen Grekçeye, Doğu bölgelerinde ise Süryaniceye bağımlıdd. Ancak halkın büyük bir çoğunlu bu iki dili de anlamadığı için yabancı bir dil ile okunan litürijinin ve duaların toplumda anlaşılabilmesi için ayinler için kilisede kendine özgü iki sınıf oluşturulmuştu. Kılıç, Ermeni din adamlarının alfabeden ve yazılı edebiyattan mahrum olmayı Kilisenin mevcudiyeti ve bağımsızlığı için bir engel olarak gördükleri için kendilerine has bir alfabenin icadını zaruri gördüklerini kaydeder (Kılıç, 2010).

Ermeni ailelelerinin entelektüel yapıda Bizans'a yerleşme tarihinin ise 6. yüzyılda gerçekleştiğine işaret eden kaynaklara göre, bu yüzyıla kadar Makedon hanedanlığının İmparator I. Basil (867-86) tarafından kurulmuş olması nedeniyle Bizans elitleri arasındaki Ermeni varlığ 1 ve edebiyatı ihmal edilmiştir (Hovannisian \& Payaslian, 2019:1-174). ${ }^{1}$

$1 \quad$ Adalian’a göre ise Ermeni entelektüellerinin eserleri 4. yüzy1ldan itibaren Ermeni edebiyatında görülmeye başlanmıştır. 4-7. yüzyıllar arasını Alın Çağ olarak tanımlayan Adalian, 7-12 yüzyıllar arasının ise Gümüş Çağ olduğunu kaydeder. 13. yüzylıı Ermeni edebiyatının Bronz dönemi 
Ermeni modernleşme hareketlerinin çok daha eski tarihlere dayandığını kaydeden Robert Thomson'a göre ise, Ermeniler tarihsel olarak çok eski dönemlerden beri antik dünyanın önemli üniversitelerinde çalı̧ıyordu. Özellikle 6. yüzyıldan itibaren Hristiyan Konstantinapol'in Atina Paganizminin yerini almaya başlamasıyla birlikte, Maştots döneminden itibaren Bizans ile tarihi Ermenistan arasında düzenli gidiş gelişlerin başladığına ve bu dönemde Ermenilerin çalı̧̧malarını sürdürmek için sık sık Bizans’a gidip gelmeye başlamış olduğuna işaret edilir. Bu dönemde bazı Ermeniler, Bagrevand’lı Davit gibi, Bizans'ta kalırken bazıları ise, Siunik'li Stepannos gibi, Yunancadan çevirdikleri eserlerle geriye dönmüşlerdir. Diğer öğrenme merkezlerinden ziyade Konstantinapol Ermenilerin ilgilerinin seküler edebiyata ve erken kilise yazarlarının yazılarına yönelmelerini sağlamışır. Elbette bu erken Ermeni Kilisesi döneminin ve Ermeni kültürünü genel olarak güçlü bir şekilde etkilemiş olan Süryani mirasının ihmal edilmesi anlamına gelmemektedir.

Thomson'a göre Konstantinapol, Ermeni ilim ve bilim dünyasının şekillenmesinde olağanüstü bir etkiye sahip olmuştur. Ermenilere ait ilk 2. ya da 3. yüzyıllardaki kanıtlar Maştots'dan sonra oldukça sınırlıdır. Sonraki tarihçilerin daha ziyade öncüllerinin kaydetmiş olduğu efsanevi materyalleri eklediklerini kaydeden Thomson'a göre tüm bunlara rağmen Ermeniler için Konstantinapol "bilimlerin yuvası" olarak sayg1 duyulması gereken bir şehir olmuştur (Thomson, 2010:37-38).

Shirinian'a göre 9. yüzyılda Bizans egemenliğinde yaşayan Ermeniler arasında Konstantinapol'de de ünlü Ermeni entelektüeller bulunmaktaydı. Bunlar arasında Konstantinapol'ün I. Patriği Photius, Gramerci John ve Matematikçi Leo en ünlüleriydi. Teolojik konuların yanı sıra bilimsel konularla da yakından ilgilenen Gramerci John ve Matematikçi Leo 9. yüzyılda toplumun dikkatini felsefe alanına çekmiştir. "Klasik öğrenme dürtüsünün” ortaya çıkmasında ciddi bir etkisi olan Patrik Photius ise aynı zamanda bir ressamdi. Matematikçi Leo aynı zamanda felsefe, belagat, gramer, şiir, doğa bilimleri ve özellikle astroloji konularında da çalışmalarda bulunan bir entelektüeldi (Shirinian, 2010: 56-57). Patrik I. Photius'un kendi dönemi içinde en büyük Ermeni entelektüellerinden biri olduğuna işaret eden Shirinian’a göre, Photius aynı zamanda becerikli bir politikacı ve başarılı bir yazardı. Onun ansiklopedik bilgisi teoloji, tarih, felsefe, bilim, sağlik, hitabet, romantizm ve sözlük alanlarına sayısız eserler kazandırmı̧sır (Shirinian, 2010: 64). Bu kapsamda

olduğunu belirten Adalian, 14. yüzyı1 için Demir Çağ, 15-17. yüzyılların ise Toprak Çağı tabirlerini kullanmış, 17-19. yüzyıl arası dönem ise Bozulma dönemi olarak tanımlamıştır (Adalian, 1992:38; Avakian, 1998: 155-158). 
9. yüzyılın Konstantinapol'deki Ermeniler açısından oldukça verimli bir dönem olduğunu söylemek mümkündür. Shirinian’a göre Ermeniler söz konusu dönemde tüm siyasi, dînî, kültürel ve askeri alanlarda en yüksek pozisyonlara gelmeyi de başarmı̧̧lardır (Shirinian, 2010: 72).

Davut Kilıç Ermeni Kilisesinin Eçmiyazin'de kurulmuş olmasına rağmen, siyasi otoriteyi takip etmeyi uygun gördüğü için tarihte daima siyasi otorite ile birlikte onlarla yer değiştirmek durumunda kaldığına işaret eder. Bu noktada 485 yılında Divin'e, 901 yılında Ani'ye, 1147'de Rumkale'ye [Kilikya] taşınan Katoğikosluk'un Rumkale'de 1292 yılına kadar kaldıktan sonra şehrin Memlukluların eline geçmesiyle birlikte Sis'e nakledildiğine işaret eder. Kilikya Krallığı'nın 1375 yılında ortadan kaldırılmasıyla birlikte Katoğikosluk burada bir müddet daha kaldığını ve Katoğikosluğun, Roma Kilisesi’nin nüfuzuna girdiğini gören Ermenilerin bir Sinod toplayarak Eçmiyazin'e geri dönme kararı aldıklarını belirtir. Kılıç 1441 yılında ise Ermeni Kilisesinin ilk doğduğu yer olan Eçmiyazin'e tekrar taşındığına işaret eder (Kılıç, 2010: 1853-1854).

Mikhitaristler arasında Ermeni grameriyle ilgili kaleme aldığı eserlerle bu alandaki çalışmaları zirveye taşıyan Arsen Bagratuni de dönemin önde gelen Ermeni kalem erbabından olup, 7-11 yüzyılları arasındaki dönem için Sahak, Agatangeghos, Biuzandatsi, Eznik, Eghishe, Koriun, Khorenatsi vb. isimlere yer vermiş, özellikle Mandakuni ve Parpetsi'nin eserlerine dikkat çekmiştir. Bagratuni ayrıca bu dönemde Ermeni edebiyatı açısından Gümüş Çağ’da öne çıkan Anania Shirakatsi, Grigor Arsharuni, Ignatios, Sargis, Nerses Şnorhali, Mekhitar Gosh vb. Ermeni yazarların isimlerinin altını da çizer (Adalian 1992:25-34, Avakian 1998:161-162). Ermeni filoloji çalı̧̧malarının rasyonel bir biçimde dönemsel olarak ayrılmasında Bagratuni döneminde yapılan çalışmaların önemli bir etkisinin olduğunun da belirtilmesinde yarar vardır (Adalian 1992:27). Bilim insanı ve gramerci olarak da bilinen Bagratuni'nin Homer, Virgil ve Milton'dan Ermeniceye çeviriler yaptığ ve kendisinin de Hayk adlı bir destan kaleme aldığı bilinmektedir (Aslan 2005:122). Ermeni filolojisinin büyük öncüsü ve geçiş neslinin önde gelen temsilcisi olan Hovsep Gaterjian (1820-1882) da çağın gereklerine uyum sağlamak için gerekli olan çalışmaları yapmış odak Mıkhitarist isimlerden biridir. 1833 yılında Viyana'ya giden Gaterjian Mikhitaristler arasında efsane bir isim olarak kabul edilmektedir. Katolik ve Protestan Ermeniler tarafından modern eğitimin pek de sıcak karşılanmadığı bir süreçte Gaterjian, Mikhitarist arkadaşlarıyla birlikte modern eğitimin oluşturulması konusunda yoğun bir çaba sarf etmiştir. Çağdaşları olan Mikayel Chamchian, Arsen Bagratuni, Gevond Alişan, 
Arsen Aytenyan'la birlikte yayın faaliyetlerine başlamadan önce Mıkhitar okullarında eğitimci olarak görev yapmış dönemin önde gelen Mıkhitarlarındandır (Adalian 1992:59, Adalian 2010:304). Benzer şekilde Gaterjian'ın formülasyonunun Bagratuni dönemi ile benzer özellikler taşıdığı da kaydedilmiştir (Adalian 1992:54). Gaterjian dünyaya evrensel bir Ermeni tarihi sunarken, Karacachian ise antik Armenia'nın eleştirel bir tarihini dünyaya sunmuştur (Aslan 2005:122).

On ikinci yüzyılda edebî dille halk dili arasında ciddi farklılıklar ve ayrışmalar ortaya çıkmıştır. Bu durum Ermeni entelektüellerinin çalışmalarını da önemli ölçüde etkilemiştir. Özellikle Orta Ermenicenin Kilikya’daki Ermeni Krallığı'nın resmî dili olmasıyla Eski Ermenice ve Orta Ermenice bir arada kullanılmaya başlanmıştır. Bu dönemde resmî belgeler ve az sayıda yeni eserin Orta Ermenice ile yazıldığı, Eski Ermenicenin ise kilise dili ve klasik yazı dili olarak kaldığı anlaşılmaktadır. Bu ayrım eğitim sisteminde de kendisini göstermiş ve Anadolu gibi batı bölgelerde Orta Ermenice, bugün Ermenistan'ın bulunduğu doğu bölgelerinde ise Eski Ermenicenin ağırlık kazanmaya başladığı kaydedilmektedir (Çakmaklı Mehdiyev 2014:2).

Ermeni sanatkarlarının Osmanlı başkentine soyut olan seküler ve dînî sanat alanlarına somut bir şekil verdiklerini kaydeden Ronald T. Marches ve Marlene R. Breu, bu stilin daha sonra Konstantinapol stili olarak şekillendiğine ve bu şekilde adlandırıldığına da dikkat çekerler. 17. yüzyılda İstanbul'daki Ermeni nüfusu içerisinde bu Konstantinapol stilinin giderek evrildiği ve tarihi Armenia bölgesinden gelen Ermeni nüfusuyla birlikte kentsel maddi kültürünün şekillendiği de kaydedilmiştir. 18. yüzyıla gelindiğinde Avrupa kültürünün oryantal bir tadla İstanbul'u beslediğini ve şehri daha kozmopolit bir atmosfere büründürdüğünü ve Ermeni kilise sanatının da bu durumdan etkilendiğine dikkat çekilmiştir (Marchese \& Breu, 2010: 102). 17. yüzyılda seçkin Ermeni elitleri arasında ilk sırada Eremya Çelebi Kömürciyan'ın geldiğini kaydeden Oshagan’a göre, Kömürciyan 17. yüzyılda Batılı anlamda Hümanist felsefe eğitimini almı̧ en iyi aydınlardan biridir ve aydınlanma sürecini de başlatan bir aydındır (Oshagan, 1999: 150-151).

Vahe Oshagan 18. yüzyılın bazı araştırmacılar tarafından "Aydınlanma” dönemi olarak tanımlandığını kaydederken Ermeni elit sınıfının bu süreçte hayatta kalma, kilisenin korunması, var olan kültürün aktarılması, ulusal özgürlük ve Ermeni yurttaşların bilinçlendirilmesiyle ilgilendiğine işaret eder. Ermeni elit sınıfi ile 18. yüzyıl Avrupası arasında daha güçlü bir bağlantının olduğunu kaydeden Oshagan, 17. yüzyıldaki bağın ise daha ziyade basım ya- 
yın faaliyetleri üzerinden gerçekleştiğine değinir ve bu dönem yayınlarının genellikle dinî yayınlar olduğuna işaret eder (Oshagan, 1999: 146-147).

Ermeni entelektüellerle ilgili bir diğer önemli kaynağın da Ermeni Mıkhitaristler olduğunu söylemek mümkündür. Ermeni Mikhitaristlerin ilk modern Ermeni entelektüeller olduğunu kaydeden Rouben Paul Adalian, 18. ve 19. yüzy1llarda manastırlarda eğitim alan Ermenilerin bu dönemde Ermeni tarihi, dili ve edebiyatı konularında çok sayıda fikirler ve eserler ortaya koyduklarına dikkat çeker (Adalian, 1992: VII). Bu noktada özellikle 18. yüzyılda Mıkhitaristlerin Doğu ve Batı arasında adeta bir köprü vazifesi gördükleri ve özellikle de kültürel, tarihi, linguistik ve dinî konularda birçok Avrupalı düşünce ve girişimin Ermeni düşünce sisteminde yer almasında önemli rol oynadıkları bilinmektedir (Marchese \& Breu, 2010:120; Walker, 1980:5051). Bu anlamda 18. yüzyılın ilk yarısında yaşamış olan Sivaslı Başrahip Mıkhitar'ın çalışmalarının ise Avrupa aydınlanmasından etkilendiği ve hatta bu aydınlanmanın bazı izlerini taşıdığı da ileri sürülmektedir (Zekiyan, 2001: 22; Avakian, 1994: 167-168; Şahin, 2008).

Adalian'a göre Ermeni Mıkhitaristlerin sayısı modern dönemlere yaklaşıldıkça azalsa da ürettikleri eserlerin, açtıkları okulların, yayınladıkları dergilerin ve bastıkları eserlerin sayısında bir azalma olmamıştır. Mıkhitaristlerin altın döneminin 19. yüzyıl olduğuna işaret eden Adalian'a göre M1khitaristlerin en verimli, en orjinal ve en değerli eserleri de bu yüzyılda ortaya çıkmıştır. Özellikle Ermeni kültürünün şekillenmesinde de bu zaman diliminin oldukça önemli olduğuna vurgu yapan Adalian, bu zaman diliminde Ermeni Mikhitarsitlerin bilimsel metodlarla çok sayıda eser ortaya koymayı başardıklarının altını çizmiştir. Ermeni Mıkhitaristlerin düşünce dünyalarının zenginliğinin, rasyonel düşünce yapısının şekillenmesinde de etkili olduğu, sadece Ermeni toplumunu değil tüm dünyadaki insanları etkilediğine dikkat çekilmiştir (Oshagan, 1999:153; Adalian, 1992: 2).

Ermeni Mıkhitaristler arasında sosyal bilimler alanında özellikle de dil, sözlük, teoloji, tarih, felsefe, çeviri ve gramer kitapları konusunda çok sayıda Ermeni entelektüel isimden bahsetmek mümkündür. Bunlar arasında Mikayel Chamchian, Minas Bzhskian, Harutiun Avgerian, Gabriel Avetikian, Mkrtich Avgerian vb. isimlerden bahsedilebilir (Adalian, 1992: 17-23). Ancak söz konusu Ermeni Mıkhitaristler gerek yaşadıkları dönem, gerekse Türkçe eserlerinin bulunmayışı nedeniyle araştırmanın sınırları dahilinde değildir. 
Ermeni entelektüellerinin tarihsel olarak ortaya çıkış sürecine bakıldığında, Ermeni milletinin dinî-feodal yönetimden demokrasiye geçiş sürecindeki mücadelesinin bu oluşumda önemli bir etkiye sahip olduğu söylenebilir. Artinian'a göre bu süreç genel hatlarıyla ruhban ve soylular (amiralar) ile orta sınıf grup arasındaki mücadeleye dayanmıştır. Örgütlü bir orta sınıfın çabaları sonucu Ermeni toplumunda bir değişim ve dönüşüm sürecinden geçildiğini kaydeden Artinian'a göre bu yolda Hristiyanlığın sivillerin kilise işlerine dahil olması konusundanki tolerasyonu ve Osmanlı İmparatorluğu'nun dinî gruplara yönelik uyguladığı hoşgörü politikasının etkisi yadsınamaz. Bu noktada Ermeni toplumunun Osmanlı'yla benzer şekilde 19. yüzyıldan itibaren Batı uygarlığından etkilenmeye başladığı ve bu etkilenmenin de ilk etapta Katolik ve Protestan misyonerlerinin faaliyetleri aracılığıyla gerçekleştiği öne sürülebilir (Kılıç, 2006:116-129; Kılıçdağı, 2010: 333-342; Artinian, 2004:122-123). Kilıç’a göre bu dönemde Gregoryen mezhebinden Katolikliğe geçen Ermenilerin sayısında ciddi bir artış olmuş, Katolikliğe geçen Ermenilerin Cizvit Papazlarla işbirliği yapmaları ise Ermeni toplumunda olayları iyice çığırından çıkarmıştır (Kılıç, 2006:111-126). Kılıç benzer bir durumun Gregoryen Ermenilerin Protestanlığa geçişinde de yaşandığından da bahseder (Kılıç, 2006: 157-158). Bu durum beraberinde hem dönemin baskın kültürü olan Fransız etkisini hem de diğer Batılı devletlerin Osmanlı İmparatorluğu'na baskılarının önünü açmıştır. Böylelikle Batıda eğitim alan Genç Ermenilerin, sadece Ermeni toplumu değil Osmanlı İmparatorluğu'ndaki diğer vatandaşları da etkiledikleri görülmektedir.

\section{Osmanlı İmparatorluğu’nda Ermeni Entelijansiya'nın Oluşumu (1800-1923)}

Tanzimat dönemiyle birlikte gerek Avrupaya eğitim amacıyla gitmiş gerekse de görevi gereği Avrupa'da bulunmuş Ermeni entelijansiya için dünyadaki gelişmeleri yakından görme ve izleme imkanı doğmuştur. Bu durum beraberinde 19. yüzyılda Avrupa tarihinin, dilinin, edebiyatının, siyasetinin, ticaretinin kısacası her türlü gelişiminin yakından takip edilmesine ve Osmanlı'ya yansımalarına neden olmuştur. Avrupa'da eğitim almış Genç Ermeniler, özgürlük, demokrasi, eşitlik ve milliyetçilik gibi liberal ve ilerici düşünce yapısından etkilenmiş ve amiralara karşı orta sınıfla işbirliği içinde hareket etmiştir. 1856 yılında ilan edilen Islahat Fermanı da Genç Ermenilerin düşüncelerini daha rahat bir biçimde ortaya koyma imkanı sağlamıştır (Kılıç, 2008: 117-136; K1lıçdağ çilik akımının da bir bakıma seküler düşüncenin doğmasında etkisi olmuştur (Panossian, 2006: 1008). Osmanlı Devleti’nde önemli görevlerde yer alan 
amiralar büyük ölçüde muhafazakâr ve Gregoryen mezhebine mensup iken, Avrupa'da eğitim görmüş Genç Ermenilerin bu gruba karşı almış olduğu tavır ve eleştiriler zaman içerisinde Ermeni toplumu bünyesinde çatışma alanı yaratmıştır. Nitekim bir süre sonra Genç Ermeniler’in yoğun çabaları sonucu Ermeni Milleti Nizamnamesi'nin hazırlanması, Genç Ermenilerin önemli kazanımları arasında ilk sırada yer almıştır (Kılıç, 2006:172-184; Kılıç, 2019: 629; Tok, 2009: 22-24, Bayır, 2019:11-36; Güllü, 2019:593-628). 1863 Ermeni Milleti Nizamnamesi’nin Osmanlı Ermenilerini devlete bağlamak yerine bağımsızlığa giden yolda misyonerlerin de etkisiyle Ermenilik şuurunu ve kimliğini ön plana çıkarmış, buna göre Ermeni Milleti Nizamnamesi Osmanlı Ermeni toplumunu daha önceden etkilemeye başlayan kültürel Rönesansın da etkisiyle milli bilinci geliştirme noktasında bir dönüm noktası olmuştur (Kılıç, 2019: 629).

Osmanlı İmparatorluğu'nda modernleşme ya da yenileşme hareketleri kapsamında öğrencilerin Batılı ülkelere eğitim amaçlı gönderilmesinin önemli bir yeri vardır. Bilindiği üzere Batılı ülkelerdeki bilim, sanayi, teknik, tıp vb. alanlardaki birçok gelişme bu öğrenciler üzerinden ve onların ürettiği eserler aracılığıyla İmparatorluğa gelmiştir. Bu noktada Osmanlı İmparatorluğu'nun yurt dışına öğrenci gönderme konusunda herhangi bir din, dil veya etnik grup farkı gözetmediğini de belirtmekte yarar vardır. Osmanlı İmparatorluğu'nda yurt dışına öğrenci gönderilmesi konusunda ilk adımlar 1813 yılında Mehmet Ali Paşa tarafindan atılmış ve öğrenciler ilk olarak Milano, Floransa ve Roma’ya gönderilmiştir. İlk zamanlarda matbaacılık alanıyla ilgili olarak eğitime gönderilen öğrencilerin daha sonra özellikle Paris'e askeri alanda eğitim almak üzere gönderildiğini söylemek mümkündür. Öğrencilerin devlet eliyle gönderilmesinin yanı sıra varlıklı Ermeni aileler tarafından desteklenerek veya kendi imkanlarıyla Batılı ülkelerdeki üniversitelerde eğitim görmeye gidenler de olmuştur (Kırmızı, 2018: 60-61).

Osmanlı eğitim sisteminde bir değişim ve dönüşüm ortamının başlatılmasında başta Reşit Paşa olmak üzere, Ali ve Fuat Paşaların çalışmalarının önemli bir etkisi olmuştur. Bu gelişmeler Osmanlı İmparatorluğu'ndaki birçok kesimi olduğu gibi Ermeni toplumunu da etkilemiş ve sadece 1840-1850 yılları arasında altmışa yakın Ermeni öğrenci Fransız okullarından mezun olarak İstanbul'a gelmiştir (Artinian, 2004:74-75). Batının yanı sıra söz konusu dönemde Çarlık Rusya'sında gizli faaliyetlerde bulunan sosyal demokrat hareketler de Ermenilerin düşünce yapısını etkilemiştir (Panossian 2006: 149; Somel, 2011: 88). Bu eğitimler sonucunda istenmeyen bazı durumlar 
yaşansa da aslında Batı'ya özellikle devlet tarafından gönderilen öğrencilerin ilk etapta devletin ihtiyacı olan alanlarda Batı'nın teknik, askeri, sanayi vb. alanlardaki üstünlüğünün yakalanması hedeflendiği anlaşılmaktadır. Ayrıca yurtdı̧ına eğitim amaçlı gönderilen gayrimüslim öğrenciler arasında Ermeni ögrencilerin ilk sırada geldiği ve öğrencilerin yoğun olarak Fransa , İngiltere, Avusturya, Yunanistan, İsviçre, Rusya ve İtalya gibi ülkelere gönderildildiği de söylenebilir. ${ }^{2}$ Paris'te Muradyan Okulu, İtalya'da ise Rafaelyan Okulu Ermeni entelijansiyasının merkezi haline gelmiştir.

1839-1876 yılları arasında Osmanlı İmparatorluğu'nun sadece Fransa'ya gönderdiği öğrenci sayısına bakıldığında öğrencilerin \%68'nin yani 116 öğrencinin Müslüman, \%32'sinin yani 78 öğrencinin ise gayrimüslimlerden oluştuğu görülmektedir. Bu rakamlar sadece Ermenilerin değil diğer etnik yapıya sahip gayrimüslimlerin de bu eğitimden faydalandığını göstermesi açısından önemlidir. Askerlik, tıp, hukuk ve mühendislik eğitim için Fransaya gönderilen öğrencilerle benzer şekilde diğer ülkelere de çok sayıda Ermeni öğrencilerin gönderildiği ve bu öğrencilerin ülkelerine döndükten sonra ilgili alanlarda ciddi çalışmalar yaptıkları bilinmektedir (Şişman 1998: 11).

Söz konusu öğrencilerin yurda döndükten sonra görev aldıkları kamu kurum ve kuruluşlarının modernize edilmesinde Türklerle birlikte görev almışlardır. $\mathrm{Bu}$ durumun en belirgin kanıtları arasında söz konusu Ermeni entelektüellerinin Osmanlı Türkçesi ile kaleme aldıkları eserlerdir.

Ermenilerin 19. yüzyılda beşeri bilimler alanında ve özellikle sözlükler konusunda bu kadar ön plana çıkmalarında Mikhitaristlerin önemli bir etkisi olmuştur. Mikhitaristler bu dönemde Katolikleşme konusunda ciddi bir başarı elde etmiş ve bu nedenle Avrupa akademilerinde de sayg1 ve takdir görmüşlerdir (Adalian, 1992:21). Bu anlamda Batılı ülkelere eğitim amaçlı giden Ermeni gençleri yurda döndükten sonra tıpkı sosyal bilimlerde olduğu gibi birçok alanda öncü olmuş ve devletin en önemli kademelerinde görev almışlardır. Böylelikle Ermeni gençleri aracılığıyla Avrupa’nın ve Batılı düşünce yapısının Osmanlı'da yerleşmesi noktasında yurdışında eğitim alıı̧̧ Ermeni entelijansiyanın da bir katkısının olduğunu söylemek mümkündür.

Genel hatlarıyla Ermeni gençlerinin yurtdışında eğitim almasıyla birlikte, Avrupa'da eğitim görmüş Ermeni entelijansiya ile Ermeni zengin kesimini oluşturan amira sınıfı arasında bir çekişmenin görülmeye başladığını söylemek

$2 \quad$ Bu konuda yapılmış en kapsamlı çalışmalar arasında Adnan Şişman’ın Tanzimat Döneminde Fransa'ya Gönderilen Osmanl Ögrencileri: 1839.1876 adlı eseri ilk sırada yer almaktadır. Adnan Şişman, Tanzimat Döneminde Fransa'ya Gönderilen Osmanlı Ögrencileri: 1839·1876, Ankara, 2004. 
mümkündür (Bu konuda detaylı bilgi için bkz: Kilıç, 2008:132-141; Artinian, 2004:10). 19. yüzyılda Ermeni entelektüellerinin Avrupa eğitim almaları ve pozitivist düşünce yapısından etkilendiğini kaydeden Artinian, bazı Ermeni entelektüellerinin 1848 Devrimi’ni yaşamış olmalarının da düşünce yapılarının şekillenmesinde etkili olduğuna vurgu yapmıştır (Artinian, 2004: 13).

Ermeni entelijansiyanın Batı dünyası ile teması bir süre sonra kendi toplumlarındaki dînî yapıları, kurumları ve din adamlarını sorgulamaya başlamalarına da neden olmuştur. Bu noktada aydınlanma sürecinin beraberinde Batı üzerinden Ermeni entelijansiyanın oluşmasında ciddi bir rol oynadığ1 söylenebilir (Kılıç, 2006:61-69; Deveci Bozkuş, 2020:413-426). Ancak sadece Batı düşüncesi değil diğer faktörlerde Ermeni entelektüel dünyasının oluşumunda etkili olmuştur. Bu noktada misyonerlerin özellikle de Amerikan Protestan misyonerlerinin Ermeni entelektüel dünyasının oluşmasına katkı sağladığını ve bu noktada ABCFM'nin oldukça etkili sonuçlar elde ettiğini de söylemek mümkündür.

İstanbul Ermenleri arasında 19. yüzyılın sonu ile 20. yüzyılın başında, kendi içinde de geleneksel ve modern ayırımı şeklinde bir ayırımın ve bir gerginliğin olduğundan da bahsetmek mümkündür. Söz konusu dönemde özellikle yaşam biçimi ve değerlerin sıkça sorgulandığını söylemek mümkündür. Ancak bu gerginliğin sadece Ermeni toplumuna has değil Osmanlı'daki Türk entelektüellerin de benzer bir kaygı içinde oldukları görülmektedir (Kılıçdağ1, 2010:234).

Ermeni entelijansiyanın söz konusu dönemler içerisinde ağırlıklı olarak Fransız entelektüel dünyasından etkilendiğini söylemek mümkündür. Nitekim öğrencilerin büyük oranda gerek devlet gerekse de bireysel anlamda yurtdışı eğitimi için Fransayı tercih etmesi beraberinde Fransız kültürünün toplumda daha fazla yer etmesinin de önünü açmıştır (Bu konuyla ilgili detaylı bilgi için bkz: Şişman 1998: 11, Şişman 2004). Hovsep Gaterjian'a göre ise Osmanlı İmparatorluğu'nda Ermeni entelektüeller sadece Fransız değil, biraz Alman ve kısmen de İngiliz etkisi altında kalmışlardır (Adalian, 1992: 50-52). Kuşkusuz sadece Fransa değil söz konusu dönemde eğitime gidilen hemen hemen her Batılı ülkedeki gelişim Ermeni entelijansiya aracılı̆̆ıyla yurda getirilmiştir. Söz konusu dönemde Ermeni entelijansiyanın oluşumunda sadece erkekler değil Ermeni kadınlarının da bu sürece doğrudan katkıda bulunduklarını söylemek mümkündür. Düssap, Zabel Yeseyan, Sibly (Zabel Asadur), Ishugi Minasian, Hayganush Mark vb. dönemin önde gelen Ermeni kadın entelektüelleri olmuşlardır. 
İstanbul'daki Ermeni toplumu her ne kadar tarihi Ermeni anavatanından oldukça uzakta olsa da İstanbul'daki Ermeniler 19. yüzyılda şehri önemli bir entelektüel merkeze dönüştürmüştür. Günümüzde ise İstanbul'daki toplum, diasporadaki ve mevcut Ermenistan'daki Ermeniler bu kültürel zenginliğin kalıntılarından faydanlanmaktadır. Bu kültürel zenginlik ise büyük oranda Srpuhi Düssap, Zabel Yeseyan, Hagop Baronian ve Daniel Varoujan döneminden miras kalmıştır (Hovannisian, \& S. Payaslian, 2010: 14). Bu anlamda Erken Modern ve Modern dönemin kültürel yaşamı açısından ise Osmanlı başkentinin bir merkez olarak ön plana çıkmasında varlıklı Ermeni amira sınıfının da önemli bir etkisi olmuştur. Amiralar ayrıca İstanbul'da farklı etnik gruplar arasındaki iletişimin sağlanmasında da etkili olmuşlardır (McCabe, 2010: 196).

Ermeni entelektüellerinin bir dönem de olsa İttihat ve Terakki Cemiyeti üyeleriyle birlikte hareket etmeleri ve II. Meşrutiyet'i sahiplenmeleri Koptaş'ın da ifade ettiği gibi ülkeyi modernleştirme temelli siyasi birlikteliklerinin olduğunu ortaya koyan önemli göstergelerden biri olarak kabul edilebilir (Koptaş, 2011: 190). Bunun yanı sıra Osmanlı Devleti'nin de tebaası olan gayrimüslimleri başta eğitim olmak üzere birçok alanda Osmanlıcılık politikası çerçevesiyle yönettiğini ve belli başlı alanlarda bu politikaların olumlu sonuçlarını gördüğünü de söylemek mümkündür.

Ermeni entelijansiyanın faaliyetlerinin Ermeni toplumunda ulusal bilincin oluşmasını ve uyanmasını sağladığını kaydeden Panossian'a göre, Ermeni entelektüellerin çalışmaları Ermeni toplumunda milliyetçilik düşüncesinin oluşmasına da ciddi katkı sağlamı̧stır. Söz konusu entelijansiya eserleri aracılığıyla da Ermeni ulus ve milliyetçiliğini meydana getirmiş̧tir. Bu anlamda şair, müzisyen, ressam, heykeltraş, romancı, tarihçi, arkeolog, filolog, oyunyazarı, antropolog, folklorist vb. entelektüellerin eserlerinin ve düşünce yapılarının Ermeni ulusunun ve kültürünün şekillenmesinde etkileri olduğu kaydedilmiştir (Panossian, 2006: 180). Bilindiği üzere 1850'li yıllardan itibaren Osmanlı İmparatorluğu'nda amiraların yerini yavaş yavaş Batı'da eğitim alan Genç Ermeniler almaya başlamıştır. Vartanian'a göre 1850-1876 yılları arasında sadrazam ve hariciye nazırlarına danışmanlık görevi neredeyse tamamen Ermeni entelijansiya tarafindan yürütülmekteydi (Panossian, 2006: 148-149; Artinian, 2004: 93). Bu noktada Ermeni entelektüelllerinin özellikle de Batılı ülkelerde aldıkları eğitimlerin hem Ermeni toplumuna milliyetçilik duygularını aşıladığını hem de bir toplum, ulus bilincinin oluşmasına katkı sağladığını da söylemek mümkündür. Bu süreç aynı zamanda modern ulusal Ermeni kimliğinin oluşumunu da önemli oranda etkilemiştir. 
Batı ya da Osmanlı merkezli liberal reformların oluşum sürecinin büyük oranda Fransız ve İtalyan düşünce sisteminden etkilendiğini kaydeden Panossian, Doğu'da Tiflis ve Rusya'nın merkez olduğunu ve diğer şehirlerdeki oluşumların merkezinin ise Rus ve Alman düşünce yapısından etkilendiğine işaret etmiştir (Panossian, 2006: 130). Bu noktada Doğu'daki Ermeni entelektüeller Ermenilerin kurtuluşu için daha ziyade Rusya'yı tek çare olarak görürken, Batılı düşünce yapısından etkilenen Ermeni entelektüellerin ise kurtuluş çaresini modernleşme çabalarında aradıkları anlaşılmaktadır.

\section{Tıp Alanında Osmanlı Türkçesi İle Eserler Kaleme Alan Ermeniler}

Osmanlı İmparatorluğu döneminde sosyal bilimler alanlarının yanı sıra diğer alanlarda da Ermeni entelektüellerinin ciddi katkıları olmuştur. Bu noktada özellikle tıp alanında çok sayıda Ermeni isimden bahsetmek mümkündür. Ancak çalı̧̧ma alanımızın kapsamında sadece Osmanlı Türkçesi ile eser kaleme alanlar incelendiğinden, bu noktada Dr. Agop Handanyan ismine özellikle yer verilmesinde yarar vardır. Agop Handanyan 1834 yılında buğday tüccarı Krikor Efendi'nin oğlu olarak Diyarbakır'da dünyaya gelmiştir. Kardeşi Harutyun Handanyan ise Osmanlı İmparatorluğu'nda Dahiliye Nazırlığında Özel Kalem Müdürü olarak görev yapmıştır (Yıldırım 2016:232). 1839 y1lında Diyarbakır'dan ailesiyle birlikte İstanbul'a gelmiş, burada ilk ve orta öğrenimine Üsküdar'da başlamıştır. Camaran Mektebi’ne giden Handanyan, 1860 y1lında Mekteb-i Tibbiye-i Şahane [Askeri Tibbiye] okulundan mezun olmuştur. Agopyan Anadolu'nun bir çok yerinde askeri hekim olarak görev almış ve 1866 'da İstanbul'a döndüğünde ise Askeri Tıbbiye'de Adli Tıp [T1bb-1 Kanuni] muallim muavini olarak görev yapmıştır. Handanyan 18701875 yılları arasında ise Ayasofya İmareti'nde Çiçek Aşısı servisinde hekim olarak görev almıştır. Bazı kaynaklarda 1876 yılında Dr. Serovpe Viçenyan’ın [Serviçen] emekli olması üzerine Handanyan'ın Askeri Tıbbiye'de adli tıp müderrisliğine atandığına da yer verilmiştir. Handanyan'ın bir süre sonra Mekteb-i Tibbiye-i Mülkiye'de de adli tıp dersleri verdiğini belirten kaynaklara göre, Handanyan bu görevlerinin yanı sıra Sivil Tıbbiye Meclisi'nde genel arşivcilik alanında da çalışmıştır. Tıp alanında Sıhhiye-i Umumiye ile Askeri Tibbiye Cemiyeti üyelikleri de bulunan Handanyan 1893 yılında ise Miralay [Albay] rütbesiyle emekli olmuştur (http://www.uskudaristanbul. com/firmadetay.asp?id=2636, Erişim Tarihi:12.09.2019). 
Handanyan'ın tıp öğrencilerine verdiği dersler ve bu derslerde kullanılmak üzere Fransızcadan tercüme etmiş olduğu iki ciltlik $T \imath b b-\imath$ Kanuni eseri alanının ilk ve tek eseri olarak kabul edilmektedir. Handanyan'ın yine Kimya-yı Kanuni adlı eseri de son derece önemli bir eser olup, alanının öncü çalışmaları arasında ilk sırada yer almakta ve konuyla ilgili literatürde önemli bir başvuru eseridir (J.E. Briand \& E. Chaude, Çev: Agop Handanyan, 1892).

\section{Ekonomi/İktisat Alanında Osmanlı Türkçesi ile Eserler Kaleme Alan Ermeniler}

İktisat alanında eserler üreten, dersler veren Ermeni entelijansiya hem Osmanlı İmpratorluğu'nda önde gelen liberaller arasında yer alıyorlardı hem de Osmanlı'da liberal düşünce yapısının oluşumuna önemli katkılar sunuyorlard1. Osmanlı İmparatorluğu döneminde modern Avrupai iktisat teorileri alanındaki ilk çalışmalar J. B. Say'in Catechisme d'Economie Politique adlı eserinin Ermeni Sahak Abro tarafindan Türkçeye tercüme edilmesiyle sağlanmıştır. Bu noktada Abro'nun çalı̧̧malarının modern ve liberal ekonomik sistemlerin hazırlanmasında veya ortaya çıkmasında adeta bir mihenk taşı vazifesi gördüğ̈nü söylemek mümkündür.

İktisat alanında öne çıkan bir diğer isim ise Sakızlı Ohannes Paşa'dır. Paris Mihitaryan okulunda eğitim görmüş olan bu münevver Sakızlı Paşa olarak da bilinmektedir. Bu okuldan önce Sakızlı Paşa eğitimini Padova'da almıştır.

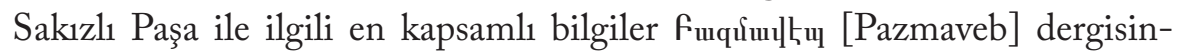
de yer almıştır. Sakızlı Paşa'nın dönemin önde gelen münevverleri arasında yer aldığına işaret eden dergide ayrıca 1847-48 tarihli öğrenim yılının sonunda Sakızlı Paşa’nın lise ikinci sınıfı bitirdiği de kaydedilmiştir. Dönemin birçok Ermeni aydını gibi devlet hizmetindeki kariyerine Babıali Tercüme Odası'yla başlayan Ohannes Paşa (Terzi 2001:26-27), 1861 y1lında kurulan Encümen-i Daniş'te görev almış, Tanzimat döneminde ise 1862-1863 yı1larında Basın-Yayın Genel Müdürlüğü görevinde bulunmuştur. Mekteb-i Mülkiye-yi Şahane'de "İlm-i Servet-i Milel, Usül-ü İdare-i Mülkiye dersleri ile Mekteb-i Fünun-1 Nefise-i Şahane” de estetik konulu dersler vermiştir. Sakızlı Paşa, 19 Kasım 1897 yılında ise Hazine-i Hassa Nazırlığı görevinde bulunmuştur. Araştırmacılara göre Sakızlı Paşa, Jön Türklerin dahi düşüncelerinden önemli ölçüde etkilendiği ve yaşadığı döneme damgasını vuran bir şahsiyet olmuştur (Soysal http://earsiv.sehir.edu.tr:8080/ xmlui/bitstream/handle/11498/19966/001507722006.pdf?se, Erişim Tarihi:12.9.2019, http://www.biyografya.com/biyografi/12387\#photo, Erişim 
Tarihi:12.9.2019). Sakızlı Ohannes Paşa, daha sonra Şuray-1 Devlet Azalığ1, Divan-1 Muhasebat Reisliği, Altıncı Daire-i Belediye Reisliği, Cebel-i Lübnan Sancağ1 Mutasarraflığ1 gibi son derece kritik görevlerde bulunmuştur (Kayaoğlu 2013:295).

İkitisat alanında özellikle Sakızlı Ohannes Paşa'nın Osmanlı Türkçesi ile kaleme aldığ1, Mebadi-i İlm-i Servet-i Milel, Usûl-i İdare: Mekteb-i Mülkiye 4. Sınıf İ̧̧in, Usûl-i idare-i Mülkiye: Mekteb-i Mülkiye Beşinci Sınıf adlı eserlerinin Batı dünyasındaki gelişmeleri ve iktisat alanındaki yenilikleri İmparatorluğa getirdiğini söylemek mümkündür. Bu anlamda Sakızlı Ohannes Paşa'nın iktisat alanında kaleme aldığı eserler aracılığıyla Osmanlı Türkiye'sinde modern iktisat alanına dair önemli bir temel oluşturduğunu söylemek mümkündür.

Sakızlı Ohannes Paşa'nın yine Fünun-u Nefise Tarih-i Medhali (Güzel Sanatlar Tarihine Giriş) adlı eseri de Osmanlı İmparatorluğu'nda 'estetik düşünce' tarihinin ilk kitabı olarak kabul edilmektedir Mebad-i İlmi Serveti Milel adlı eseri de benzer şekilde dönemin okullarında ders kitabı olarak kullanılmış olup, bu eser ise Osmanlı dönemi ilk klasik iktisat kitabı olarak kabul edilmektedir (Hür, 2014). Bu yönüyle Sakızlı Ohannes Paşa'nın hem Osmanlı Türkçesi ile yazdığı söz konusu eserler aracılığıyla hem de Fransızca-Osmanlıca sözlük çalı̧̧malarıyla Osmanlı modernleşme sürecinde önemli bir boşluğu dolduran entelijansiya arasında yer aldığını söylemek mümkündür.

\section{Hukuk Alanında Osmanlı Türkçesi İle Eserler Kaleme Alan Ermeniler}

Ekonominin yanı sıra hukuk alanlarında da benzer çalışmalardan bahsetmek mümkündür. Özellikle Nezaret Haçeryan'ın ceza hukuku konusunda kaleme aldığ Ebadi-i Hukuk-i Ceza adlı eserinin alanında ilk olduğunu söylemek mümkündür. Çalı̧̧ma kapsamında bazı Ermeni entelektüellerinin birden fazla alanda uzmanlaştığı da görülmektedir. Bunlardan biri de Orhan Vahan'dır. Vahan hem hukuk hem de kimya alanında Osmanlı İmparatorluğu döneminde alanında ilk olarak değerlendirilebilecek olan Şerh-i Kanun-u Ticaret ve Kimya Biliminin Temel İlkeleri adlı çalışmalarıyla ön plana çıkmıştır (Vahan, 1882, 2. Baskı).

Sarkis adında amira sınıfına mensup bir tüccarın oğlu olarak 1832 yılında İstanbul Ortaköy'de dünyaya gelen Orhan Vahan; Vahan Efendi, Hovhannes/Ohannes Sarkis Vahanyan, Ohan Vahan olarak da bilinmektedir. 25 Nisan 1891'de İstanbul, Taksim'de hayatını kaybeden Orhan Vahan'ın annesi Nazlı Vahanyan, Kayserili, kökenleri amira Arzumanyanlara dayanan, birkaç 
dile hakim, hayrıseverliğiyle bilien bir kadındır. Vahan Efendi'nin ailesinin kökenlerine dair çok fazla bilgi olmasa da Orhan Vahan'ın Sırpuhi adında bir kız kardeşi olduğu bilinmektedir. Vahan'ın ise Astine Vahan-Serviçen ve Araksi Vahan Gülbenkyan adında iki kızı olduğu kaydedilmiştir. 1848 y1lında ailesi tarafından Paris'e gönderilen Vahan, Tomas Terziyan'ın ifadesiyle daha gençlik yıllarından itibaren tabiat ilmine tutkun bir gençtir. Paris'te eğitimine devam ederken Dr. Nahabed Rusinyan, geleceğin ünlü edebiyatçıs1 Dr. Hovsep Şişmanyan ve diğer Ermeni entelektüellerle bir araya gelme ve tanışma firsatı yakalayan Vahan'ın buradaki Genç Ermenilerle birlikte Ara-

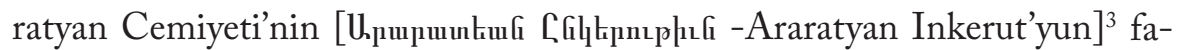
aliyetlerine katılmıştır. Paris'te dört yıl boyunca eğitim alan Vahan Efendi, 1852 yılında İstanbul'a kimyager olarak geri dönmüştür. Henüz 24 yaşındayken devlet hizmetinde görev almaya başlayan Vahan Efendi, 1865 y1lında Tercüme Cemiyeti’nin kuruluşunda üye olarak görev almıştır. Bir dönem Ahmet Cevdet Paşaya danı̧̧manlık da yapmış olan Vahan Efendi, Ticaret Mahkemeleri üyeliği ve 1868'de Divan-1 Ahkam-1 Adliye ve 1871'de Şura-y1 Devlet azası görevlerinde de bulunmuştur (Deveci Bozkuş, 2020: 413-426).

Hukuk alanında da yine diğer alanlardaki sorunlarla benzer şekilde Sarkis Karakoç (1865-1944) gibi Külliyât-ı Kavânîn adlı hukuk alanında son derece önemli eserler kaleme almış olan Ermeni entelektüeller söz konusu olsa da doğum ve ölüm tarihleri nedeniyle çalışmanın sınırları dışında tutulmuştur.

3 Genç Ermeniler tarafindan Paris'te 27 Nisan 1849'da kurulan bu dernek Paris'te bulunan tüm Ermeni gençlerinin bir araya geldiği, herhangi bir mezhep ya da politik örgüt bağlantısı olmayan Ermeni Katolik öğrencilerin de toplandığı bir kuruluştu. Burada başta Ermeni halkının eğitimi olmak üzere Ermeni dilinde, okullarında ve merkezi idarede reform konularında adımlar atılması vb. konulara yer verilmekteydi. Vartan Artinian, Osmanlı Devleti’nde Ermeni Anayasasinın Doğuşu 1839-1863, Cevv: Zülal Kılıı,, Aras Yay., İstanbul 2004, s.77-78. 


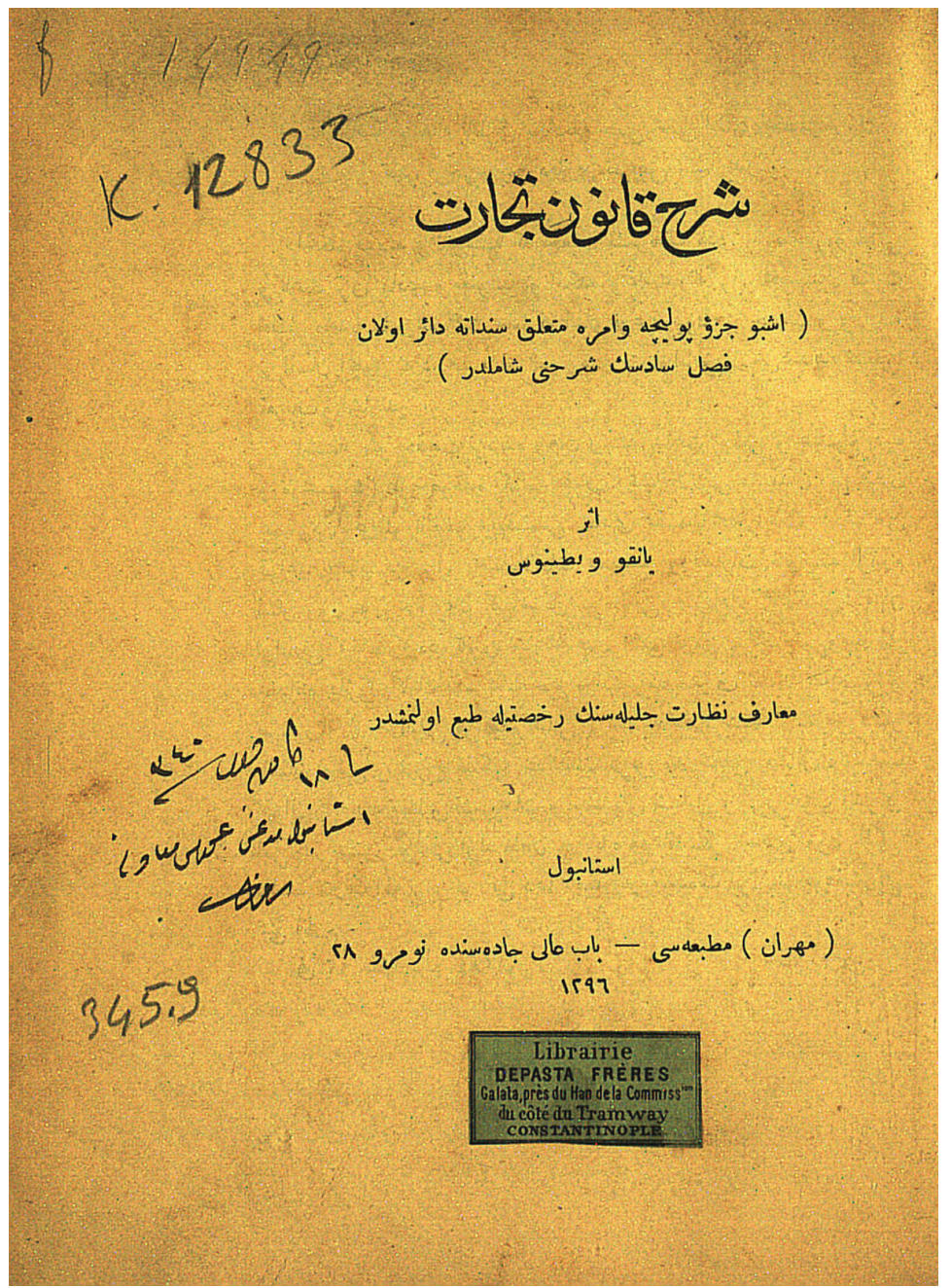

Orhan Vahan'ın Şerh-i Kanun-u Ticaret adlı eseri (Vahan 1879, I.Baskı).

\section{Tiyatro Alanında Osmanlı Türkçesi İle Eserler Kaleme Alan Ermeniler}

Sanatın pek çok alanında olduğu gibi modern Türk tiyatrosunun oluşumunda özellikle de Tanzimat ve İstibdat döneminde Avrupai tiyatroyu Osmanli’ya ilk getirenlerin yine Ermeni entelektüeller olduğunu söylemek mümkündür. Çalışma kapsamında incelenen isimlerden biri olan Tomas Terziyan'ın eserleri bu noktada oldukça önemlidir. Terziyan Osmanlı Türkçesi ile Talim-i Lisan-ı Ermeni adlı bir eser kaleme almıştır (Terziyan, 1891).

Batı Ermeni edebiyatının önemli temsilcileri arasında yer alan Terziyan 1840 yılında İstanbul'da dünyaya gelmiştir (Tuğlacı, 1992:79). Şair ve oyun yazarı 
olarak da bilinen Terziyan'ın Katolik bir ailede Rumca konuşan bir babadan ve İtalyan bir anneden doğduğu kaydedilmiştir. Terziyan mahallelerindeki Mikhitar okulunu bitirdikten sonra Venedik'teki Murad Rafaelyan okuluna gönderilmiş ve 1858 y1lında bu okuldan mezun olmuştur. Terziyan bu okulda birçok yabancı dil öğrenmiştir. Bu diller arasında İtalyanca, Grekçe, Fransızca, Türkçe, Klasik Grekçe, Latince ve İngilizcenin yer aldığı kaydedilmiştir. Terziyan ülkeye döndükten sonra kendisini öğretim işlerine adamıştır. Bir süre Nersisyan ve Nupar-Shahnazaryan okullarında eğitim veren Terziyan daha sonra Hasköy'de bu görevine devam etmiştir (Havcikyan vd. 2005: 380).

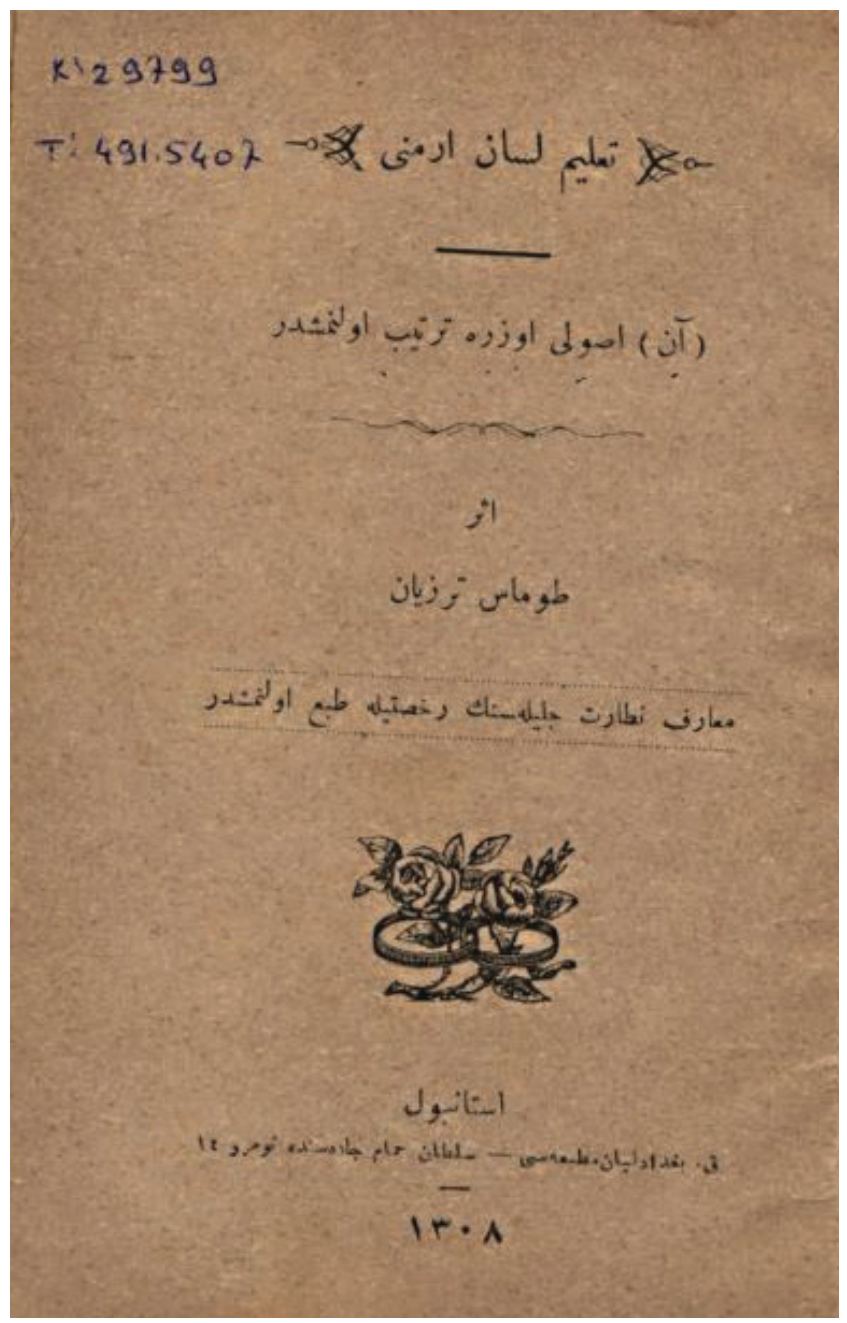

Tomas Terziyan’ın Talim-i Lisan-ı Ermeni adlı eserinin kapağı (Terziyan 1891) 


\section{Eğitim Alanında Osmanlı Türkçesi İle Eserler Kaleme Alan Ermeniler}

Ermeni entelektüellerinin topluma sundukları katkılar sadece çeviri ve kaleme aldıkları eserlerle sınırlı kalmamıştır. Aynı zamanda eğitim ve yayıncılık alanında da çok sayıda eserin basılmasını sağlamışlardır. 1899 yılında yayınlanan Maarif Nezareti yıllık istatistiklerine göre İstanbul'daki 90 matbaanın 32'sinin Ermeniler, 23'ünün Türkler, 15'inin Rumlar, 5'inin Yahudiler, 5'inin Levanten veya Avrupalılar, 2'sinin ise İranlılar tarafından işletildiği kaydedilmiştir (Budak, 2006: 137-156). Bu rakamlar söz konusu döneme dair Osmanlı İmparatorluğu'ndaki münevverlerin okuma yazma ve çeviri alanındaki yayınları ne oranda takip ettiklerine dair önemli ipuçları içermektedir.

Özellikle yurt dışında eğitim almış Ermeni entelektüellerinin çalı̧̧maları hem Ermeni toplumundaki kadınların eğitilmesi hem de Osmanlı toplumundaki Müslüman kadınların modernleşmesi noktasında etkili olmuştur. $\mathrm{Bu}$ çerçevede Ermeni toplumundaki entelektüeller 19 ve 20. yüzyıllarda kadınların eğitilmesi, eğitim düzeylerinin arttırılması, eşitlik, özgürlük ve yasal haklarının verilmesi konularında oldukça etkili olmuşlardır. Özellikle Sırpuhi Düssap, Zabel Asatur vb. Ermeni kadın entelektüelleri Türk kadın entelektüel hayatının şekillenmesinde de önemli bir rol oynamışlardır. Genç Türklerin yönetimde olduğu süreçte her ne kadar Ermeni kadın entelektüellerinin eserleri Türkçeye tercüme edilerek yayınlanmışsa da bu çeviriler tek başına yeterli olmamış daha sonra kadınların eğitimi için çeşitli kurumların açılması konusunda çalı̧̧malar yapılmıştır. Örneğin kadın öğretmen bulma konusunda 1870'li yıllara kadar ciddi sıkıntılar yaşandığını, bu sıkıntıların ancak 1870'te kadın öğretmenlerin olduğu bir kolejin açılmasıyla aşılmaya başlandığ1 görülmektedir (Safarian, 2007:142). Ayrıca söz konusu Ermeni entelektüelleri İmparatorluk sınırları dahilinde modern eğitim kurumlarının açılması hususunda da öncü olmuşlardır.

Fransız Devrimi'nden tabiatıyla en fazla Batılı devletlere eğitim amaçlı giden Ermeni entelijansiya etkilenmiştir. Bunlardan biri olan Kelekyan'ın Fransız devrimini özümsemesi bu hareketin düşünce ve fikir dünyasına dair önemli eserleri Osmanlı Türkçesine çevirmesi, kendisinin de aslında bir Jön Türk olarak adlandırılmasına dahi neden olmuştur. Nitekim Kelekyan'ın Mektebi Mülkiye'de bu konularda verdiği eğitimlerin ve kaleme almış olduğu başta $O n$ Dokuzuncu Asırda İctimai ve Siyasi Avrupa adlı eseri olmak üzere bir çok eserinde Batı'daki gelişmeleri topluma eserleri aracılığıyla aktardığını söylemek mümkündür (Kelekian, 1914). 
Diran Kelekyan, Sarraf Kirkor Kelekyan Efendînîn oğlu olarak, 1862 yılında Kayseri'de dünyaya gelmiştir (Çankaya 1969: 966). Henüz altı aylıkken ailesi İstanbul'a taşınan Kelekyan (Walker 1980:396), Hasköy Nersesyan Mektebi'nde ilkokul, Kumkapı Mezburyan Mektebi'nde ortaokul ve Gedikpaşa Surenyan Mektebi'nde lise eğitimini tamamladıktan sonra Marsilya'da ailesinden bir yakınının yanına gönderilerek Marsilya Üniversitesi Bilimler Fakültesi'ne (Faculté des Sciences) devam ederken, bir yandan da Ticaret Mektebi muallimlerinden hususi surette iktisat ve ticaret dersleri almıştır (Walker 1980:396, Gövsa 1933: 339). Kelekyan ayrıca aynı üniversitenin $\mathrm{Hu}-$ kuk Fakültesi’nde eğitimini tamamlayarak 1881 yılında İstanbul'a dönmüştür. 1894 yllında ise Yunanistan'a gitmiştir. Yunanistan'da Spectateur d'Orient gazetesinde de bir sure görev yapan Kelekyan, 1897 y1lında İstanbul'a geri dönmüştür. Bir dönem Ceride-i Şarkiye ve Surhatang gazetelerinde de çalışan Kelekyan, Ermeni Harfli Türkçe gazete olan Manzume-i Efkar'n yanı sıra yazar olarak Tarik, Sabah, Cihan, Saadet, Ceride-i Şarkıyye gazetelerinde de görev yapmıştır. Kelekyan, Ermenice yazılarının altında Klanik, Batı basınında yayınlanan yazılarında ise Vicomte de Klanik imzalarını kullanmıştır (Pamukciyan 2003: 269). Ayrıca Patrikhane çevirmenliği ve Hazine-i Hassa Sekreterliği görevlerinde de bulunmuştur.

\section{Çeviri/Edebiyat Alanında Osmanlı Türkçesi İle Eserler Kaleme Alan Ermeniler}

Ermeni entelektüellerinin en önemli katkıları edebiyat alanında gerçekleşmiştir. Modern Türk Edebiyatının doğuşunda Ermeni entelektüellerinin özellikle çevirileri ve eserleri Batılı yazar ve düşünürlerin fikirlerinin topluma aktarılmasında oldukça önemli bir rol oynamıştır.

Çalı̧̧ma kapsamında genel olarak Ermeni entelektüellerinin özelikle Bat1da eğitim almış gençlerin, Tercüme Odaları ve Hariciye'de önemli görevlere geldikleri görülmektedir. (Balc1, 2009, Balc1 2013). Bunun yanı sıra dönemin Batı dünyasında öne çıkan Alexandre Pére Dumas, Jules Verne, Victor Hugo, Sir Walter Scott vb. özellikle de Fransız yazarların romanlarını Ermenice ve Osmanlı Türkçesine tercüme eden Ermeni entelektüelleri bu konuda özellikle Dedeyan yayınları ile çalışma alanlarını oldukça genişletmiş ve Osmanlı İmparatorluğu'nda Batılı düşünce yapısının oluşumunda katkıda bulunmuşlardır (Kayaoğlu, 1998). Böylelikle bu tür edebi türler ve eserler çeviriler aracılığıyla Avrupa'nın mevcut ideolojik düşünce sisteminin hem Batı Ermeni kültürünü hem de Osmanlı'da bu yönde bir düşünce sisteminin oluşmasına katkıda bulunmuşlardır (Panossian, 2006:138-139). 
Çalışma çerçevesinde Fransız yazarların roman, hikaye ve bilimsel kitaplarının Fransa'da bulunmuş veya iyi derecede Fransızca ve Fransız kültürünü bilen Ermeni entelektüeller aracılığıla çevirildiği görülmektedir. Tanzimat ve Islahat dönemiyle birlikte bu tür eserlerin Türkçeye kazandırılması Batıdaki gelişmelerin Batılı ülkelerde eğitim almış Ermeni entelijansiya üzerinden Türk toplumuna aktarılmasını da kolaylaştırmıştır. Özellikle çeviri alanında yapılan çalışmaların 19. yüzyılın ikinci yarısında ağılık kazandığını ve bu alanda daha ziyade Fransızca eserlerin Türkçeye çevrildiğini söylemek mümkündür.

Ermeni entelektüellerin Osmanlı Türkçesine yaptıkları çevirilerin bir bakıma Batılı ülkeleri tanıma noktasında da etkili olduğu görülmektedir. Batıdaki eşitlik, özgürlük, adalet, eğitim, sosyal ve kültürel gelişmeler bu çalışmalar aracılı̆̆ıyla ülkeye getirildiğinden, bu tür eserler adeta bir köprü vazifesi görmüştür. (Ülken, 2016).

Bu eserlerin bir diğer etkisi ise yeni edebi türlerin de Türk edebiyatına girmesinde öncü olmalarıdır. Bu noktada Vartan Paşa'nın ilk Türkçe romanı olarak kabul edilen 1851 yılında kaleme aldığı Akabi Hikayesi adlı eseri son derece önemlidir.

Filoloji alanında hazırlanan eserlerin büyük bir çoğunluğunda Ermeni entelektüellerin bu eserleri hazırlama gerekçeleri arasında Türk milletinin dünyayı ve Avrupa'yı yakından takip etmek ve oralardaki gelişmeleri anlamaları için hazırladıklarına dair açıklamalarda bulundukları görülmektedir (Hindoğlu, 1831; Çetinoğlu, 2018).

$\mathrm{Bu}$ konuda özellikle sözlük alanında öne çıkan isimlerden biri de Bedros Zeki Garabedyan olmuştur. 1873 yılında İstanbul'da dünyaya gelen Bedros Zeki Garabedyan eğitim hayatına Berberyan Okulunda başlamıştır (Pamukciyan 2003: 222). Garabedyan Berberyan Okulu'ndaki eğitimini 1890 yılında tamamladıktan sonra hem mezun olduğu okulda hem de başka okullarda uzun yıllar İstanbul'da Osmanlı Türkçesi öğretmeni olarak görev yapmıştır. Üsküdar'da kendi adıyla Garabedyan Okulu'nu açmış ve burada çok sayıda öğrenci yetiştirmiştir. Garabedyan bir dönem İstanbul'daki Ermeni gazetelerinde makaleler de yayınlamıştır (Estukyan 2014).

1893 yılında Devlet Şura’sına yardımcı üye olarak seçilen Garabedyan'ın 1903 yılında ise mümeyyiz rütbesi aldığı kaydedilmiştir. Garabedyan ayrıca 1932 yılında Dolmabahçe Sarayı'nda yapılan I. Türk Dil Kurultayı'na üye olarak da katılmıştır (Pamukciyan 2003:222, Pamukciyan 2002:145). 


\section{Ziraat Alanında Osmanlı Türkçesi İle Eserler Kaleme Alan Ermeniler}

Araştırma kapsamında Ermeni entelijansiyanın Osmanlı Türkçesi eser ürettikleri bir diğer alan ise ziraat olmuştur. Tarım ve ziraat alanında özellikle Agop Zakaryan'ın İzmir'de yayınladığı eserler de oldukça ses getirmiş, Türk tarım işletmeciliği ve tarım muhasebesinin konularının tarihi gelişim sürecine önemli katkılar sağlamı̧stır.

Agop Zakaryan İzmit'in Arslanbek köyünde dünyaya gelmiştir. İlköğreniminin ardından Mersin Ziraat Mektebi'ne devam eden Zakaryan, buradan mezun olmuş, özellikle tarım ve bağcllık konusunda çalışmış ve bir süre Halkalı Ziraat Mektebi’nde tavukçuluk üzerine de ders vermiştir. Bir dönem Alemdağ Baltacı Çiftliklerinin müdürlüğünü de yapan Zakaryan'ın İzmir Tarım Müfettişiyken hayatını kaybettiği bilinmekle birlikte ölüm tarihiyle ilgili herhangi bir bilgiye ulaş1lamamıştır (Yarman 2001:322'den aktaran Çeşme 2014:73-99).

Zakaryan'ın Halkalı Ziraat Mektebi’nde çalıştığı süreçte devletin, Ziraat Bakanlığı aracılığıyla okuldaki tüm gelişmeleri yakından takip ettiğini kaydeden Özgür Yıldız, bu konuda okulda çalışacak öğretmenlerin seçiminde de devletin büyük bir titizlik sergilediğine dikkat çeker. Devletin okulda çalı̧̧mak üzere nitelikli kişileri seçtiğini ve bu okuldan mezun olanların ileride çok iyi görevlere geldiğine dikkat çeker. Yıldız söz konusu okulda görev yapan öğretmenlerden biri olan Zakaryan'ın da 1893 yılında Halkalı'daki okulda "Çiftlik İdaresi” adlı eserini kaleme aldığını ve devletin sırf bu kitap nedeniyle Zakaryan'ı Mecidi Nişanı ile ödüllendirdiğine yer verir (Yıldız 2012:323). Zakaryan'ın burada çalışırken Ameliyat-ı Ziraiye dersini verdiği de bilinmektedir (Gençoğlu 2014:289).

Ömer Yazan, Zakaryan'ın Çiftlik İdaresi adlı eserini XIX. Yüzyıl sonlarında Osmanlı tarım işletmelerinin durumuna dair gerçekçi bir çalı̧̧ma olarak değerlendirmektedir. Nitekim Zakaryan'ın gerek eserinde eleştirel bir yaklaşım sergilemiş olması gerekse de zaman zaman Avrupadaki örneklerden yararlanması ve mukayeseler yapması eserin söz konusu dönem açısından ne kadar önemli olduğunu ortaya koymaktadır. Devletin Zakaryan’ın bu çalışmasına Osmanlı tarımı açısından verdiği önemi gösteren bir diğer husus da, Zakaryan'a çalışması nedeniyle devlet tarafından Mecidî Nişanı verilmesidir (Yazan 2018: 323). Zakaryan söz konusu eserinde memuriyet süresince edindiği tecrübelerinden ve gözlemlerinden yararlanarak bu eseri hazırladığını, ziraat mekteplerinde okutulacak bir çalı̧̧ma olmaktan ziyade tarım işletme- 
lerinin yönetim ve muhasebe bilgisi ihtiyaçlarına cevap vermek için kaleme aldığını da ifade etmiştir (Yazan 2018:290-291).

Ziraat alanında Kevork Torkumyan gibi isimlerin Osmanlı Devleti tarafindan burs verilerek yurdışına ipek böcekçiliği alanında yetiştirilmek üzere gönderildiği görülmektedir. Torkumyan aldığı eğitimin ardından İstanbul'a döndükten sonra Osmanlı Türkçesi ile eserler kaleme almış ve bu eserlerden biri de 1922 y1lında İpek Böceği Beslemek ve İpek Böceği Tohumu İstibsal Etmek Usulleri adlı eseri olmuştur. Ancak Torkumyan 1859-1950 yıllarında yaşamış olması nedeniyle bu çalışmanın sınırlarına dahil edilmemiştir. (Torkumyan, 1897).

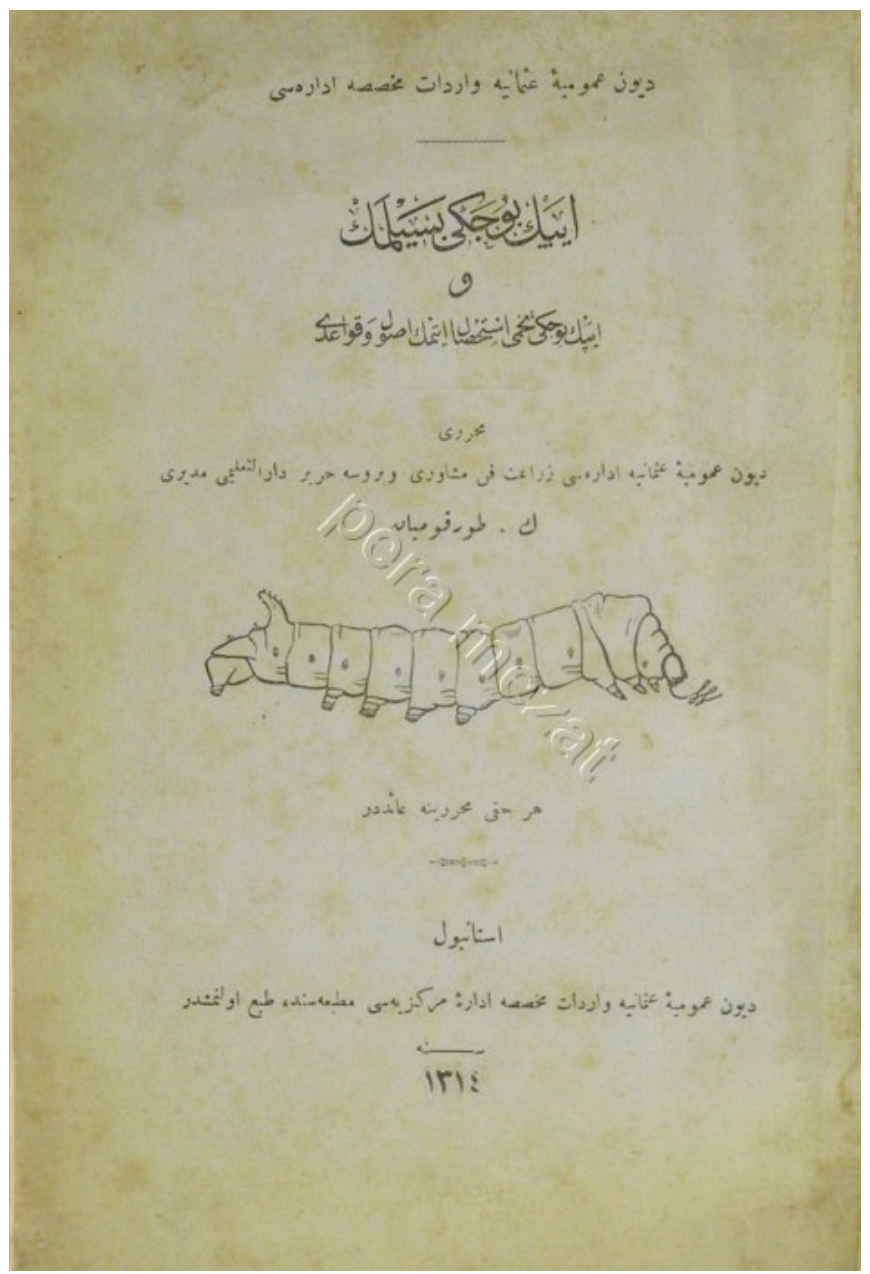

Kevork Torkumyan'ın İpek Böceği Beslemek ve İpek Böceği Tohumu İstibsal Etmek Usulleri adlı eseri, 1897. 


\section{SONUÇ}

Genel olarak Ermeni entelektüellerinin eserlerinin hem Ermeni harfli Türkçe eserleri hem Osmanlı Türkçesi ile yazılan eserleri göz önünde bulundurulduğunda Türkiye'de bilim ve kültür tarihinin kaynaklarının oluşumuna da katkı sundukları görülmektedir. Bu anlamda yurt dışına veya Batılı ülkelere eğitim amaçlı giden Ermeni gençlerinin Türk modernleşme sürecine olumlu bir katkılarının olduğunu söylemek mümkündür. Bu katkı sadece sosyal/ beşeri bilimlerle sınırlı kalmamış mühendislik, mimarlık, tıp, hukuk, ziraat alanlarında da kendînî net bir biçimde göstermiştir.

Çalışma sırasında incelenen kaynakların büyük bir çoğunluğunda Ermeni entelektüel ortamının oluşmasında Batı'da eğitim almış Genç Ermenilerin önemli bir etkisinin olduğu sonucuna varmak mümkündür. Bu noktada söz konusu Ermeni gençlerinin Batı'da özellikle de Fransa'da aldıkları eğitim zihinsel dünyalarını önemli oranda etkilemiştir. $\mathrm{Bu}$ verilerden hareketle Osmanlı İmparatorluğu'nda Ermeni entelijansiyanın başta Cemiyet-i İlmiye-i Osmaniye olmak üzere bilimsel ve kültürel kurum ve kuruluşlarda aktif olarak görev aldıkları görülmektedir. Ayrıca 1863 yılında yayın hayatına başlayan Osmanlı döneminin ilk bilimsel dergisi olarak kabul edilen Mecmua-i Fünun vb. bilimsel dergilerde de Ermeni entelijansiyanın gerek çeviri gerekse de ürettikleri eserler aracılığıyla katkıda bulundukları anlaşılmaktadır.

Tanzimat döneminde ortaya çıkan gelişmelerden Ermeni entelektüellerin büyük oranda pozitif yönde etkilendiği de görülmektedir. Bu manzaranın ortaya çıkmasında Ermeni entelijasiyanın yurtdışında aldıkları eğitimlerinin yanı sıra Tanzimat sürecini hazırlayan Türk entelijansiyanın yanında görev almış olmalarının da sürece olumlu yönde katkıları olduğu anlaşılmıştır. Bu anlamda neredeyse tüm önemli görevlerde yer alan Türk bürokratlarının ve Türk entelijansiyanın yanında Ermeni isimlerin yer aldığ Kuşkusuz bu durumun temelinde Tanzimat öncesine dayanan Ermeni toplumunun yapısının da etkisi olmuştur. Özlelikle Ermeni amira sınıfının devletle olan ilişkilerinin Tanzimat sürecine gidilen yolu hızlandırdığı da bilinmektedir. Tanzimat dönemiyle birlikte Rumlardan boşalan Hariciye, Tercüme Odası vb. bürokratik kurumlarda devletin en üst görevlerinde Ermenilerin yer almaları ve birden fazla dil bilmeleri bu görevlere gelmelerinde ve başarılı olmalarında etkili olmuştur. 


\section{KAYNAKLAR}

Adalian, Rouben Paul (1992). From Humanism to Rationalism Armenian Scholarship in the Nineteenth Century, Georgia: Scholars Press.

Art, Alif (2016). Kitap, Harita ve Gravür Müzayedesi-XI, İstanbul.

Artinian, Vartan (2004). Osmanl Devleti’nde Ermeni Anayasasi'nın Doğuşu 1839-1863. İstanbul: Aras Yayınları.

Avakian, Arra, S.(1998). Armenia: A Journey Through History, California:The Electric Press.

Avakian, Anne M.(1994). Armenian Folklore Bibliography (Vol. 11), England, London:Univ. of California Press.

Aslan, Kevork (2005). Armenia and The Armenians, New York: Elibron Classics.

Balc1, Sezai (2009). "Bir Osmanl1-Ermeni Aydın ve Bürokratı: Sahak Abro (1825-1900)”, Osmanl Siyasal ve Sosyal Hayatında Ermeniler içinde (105138). Erdal, İ. \& Karaçavuş, A. (Ed.). İstanbul: IQ Kültür Sanat.

Balcı, Sezai (2013). Babıali Tercüme Odası, İstanbul: Libra Yay.

Bamban, Robert (2019). The Military History of Armenia, London, Hayashen: Centre for Armenian Information \& Advice (CAIA) Library.

Bayır, Önder (2019). "Osmanlı Arşivi'nin Ermeni Araştırmaları Açısından Önemi ve Belgelere Göre Ermeni Toplumuyla Münasebetler”, 1000. Yılında Türk-Ermeni İlişkileri. Edt: M.S.Bilgin-Yıldız Deveci Bozkuş. Ankara:Atatürk Araştırma Merkezi Yay.

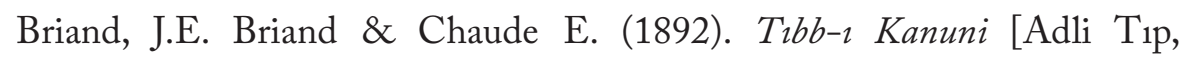
Fransızcadan çeviri], Çev: Agop Handanyan, İstanbul: Mekteb-i Tibbiye-i Şahane.

Budak, Ali (2006). "Ermeniler'in XIX. Yüzyılda Yeni Bir Hayatın ve Edebiyatın Oluşum Sürecine Katkıları”, Journal of Academic Studies (Yı1: 8, Say1: 30 Ağustos - Ekim):137-156.

Cankara, Murat (2015). “Çifte Maduniyet, Çifte İşlev: Ermeni Harfli Türkçe Basında Dil ve Kimlik”, Ankara Üniversitesi İlef Dergisi (2/2):105-130.

Çakmaklı Mehdiyev, Gaffar (2014). Ermenice Dersler (Kendi kendine Ermenice ögrrenenler için), Edt.Yıldız Deveci Bozkuş, Kayseri:Erciyes Üniv. Yayınları. 
Çankaya, Ali (1969). Yeni Mülkiye Tầribi ve Mülkiyeliler (Mülkiye șerefkitabı): Cild. Mülkiye Târibi'Nin Devamı, 1859-1968, Ankara: Ankara Üniversitesi, Siyasal Bilgiler Fakültesi Yayınları.

Çeşme, V. (2014). "Halkalı Ziraat Mektebi: Eğitimi, Eğitimci Kadrosu, Örnek Çiftliği ve Yayınları”, Osmanlı Bilimi Araştırmaları, XVI (1), 73-99.

Çetinoğlu, Sait (2018). "Artin Hindoğlu ve 1831 tarihinde yayınladığ 1 Fransızca - Türkçe Sözlük”.https://hyetert.org/2018/07/02/artin-hindogluve-1831-tarihinde-yayinladigi-fransizca-turkce-sozluk/ (E.T.12.09.2018)

Deveci Bozkuş, Yı1dız (2020). "Osmanlı Modernleşmesinde Ermeni Bir Entelektüel: Hukukçu Orhan Vahan”, History Studies, Doç. Dr. İlknur Mangır Karagöz Armağanı, 12/2, Nisan: 413-426.

Ekonomist-Devlet Adamı Sakızlı Ohannes Paşa, Erişim tarihi ve adresi: 09.08.2019. http://www.biyografya.com/biyografi/12387\#photo

Estukyan, Vartan (2014). “Agos'un arşivinden: Osmanlıca ve Türkçenin Ermeni dilbilimcileri”, Agos. Erişim Tarihi: 10.12.2014.

Gençoğlu, Mustafa (2014). "Sultan II. Abdülhamid'in Yurt Dış1 Eğitim Politikası”, Kirıkkale Üniversitesi Sosyal Bilimler Dergisi, (4/2)3: 3-73.

Gövsa, İbrahim Alaettin (1933). Meşhur Adamlar, İstanbul:Sedat Simavi Yay.I Cilt.

Güllü, Ramazan Erhan (2019). "Birinci Dünya Savaşı Öncesinde Osmanlı Devleti ile İstanbul Ermeni Patrikhanesi Arasındaki İlişkiler (1908-1914)”, 1000. Yılında Türk-Ermeni İlişkileri. Edt: M.S.Bilgin-Yıldız Deveci Bozkuş. Ankara:Atatürk Araştırma Merkezi Yay.

Handanyan, A. (t.y.). Erişim tarihi ve adresi: 02.07.2019 http://www. uskudaristanbul.com/firmadetay.asp?id=2636

Havcikyan, A. J. Franchuk, E. S., Ouzounian, N. (2005). The Heritage of Armenian Literature: From the Tradition to the Golden Age, Michigan: Wayne State University Press.

Hindoğlu, Artin (1831). Fransızca-Türkçe Sözlük, Viyana: Yayınevi Bilgisi Yok. Hovannisian, Richard G. Hovannisian \& Simon Payaslian (2010), Armenian Constantinople. USA: Mazda Publishers.

Hür, Ayşe (2014). "Bank-1 Osmanî-i Şahane'den Merkez Bankası'na”, Radikal, E.T.: 26.01.2014. 
Karataş, Şenay, Göksel Yücel, Burcu Adiloğlu (2018). "Muhasebe Eğitimine Verilen Doksan Y1llı Ömür: Kirkor Kömürcüyan”, MED -Journal of Accounting Institute. (16/59):71-80.

Kayaoğlu, Taceddin (1998). Türkiye'de Tercüme Müesseseleri, İstanbul: Kitabevi Yay.

Kayaoğlu, T. (2013). Osmanlı Hâriciyesinde Gayr-i Müslimler (1852-1925), Ankara: TTK Yayınları.

Kelekian, Diran (1914). On Dokuzuncu Asırda İctimai ve Siyasi Avrupa, 18621918, Dersaadet: Sabah Matbaas1.

Kılıçdağı, Ohannes (2010). “The Constitutional Truths” Hovsep Vartanian” Modernism: Representations of National Culture: Discourses of Collective Identity in Central and Southeast Europe 1770? 1945: Texts and Commentaries. Eds: A. Ersoy, G. Maciej \& V. Kechriotis. Volume III/2 Budapest - New York: Central European University Press, (Vol. 3, No. 2): 333-342.

Kılıç, Davut (2010). “Ermeni Kimliğinin İnşasında Kilisenin Rolü”, Prof. Dr. Harun Güngör Armağanı, Haz. Mustafa Argunşah-Mustafa Ünal, İstanbul: 124 Kesit Yay.

Kılıç, Davut (2006). Osmanlı Ermenileri arasında Dînî ve Siyasi Mücadeleler, Ankara:Atatürk Araştırma Merkezi Yay.

Kılıç, Davut (2008). Taribten Günümüze İstanbul Ermeni Patrikhanesi, Ankara:Atatürk Araştırma Merkezi Yay.

Kılıç, Davut (2019). “1915 Olaylarının İnkişafında İstanbul Ermeni Patrikhanesi'nin Etkisi Üzerine Bir Bakı̧̧ (1908-1915)”, 1000. Yılında TürkErmeni İlişkileri. Edt: M.S.Bilgin-Yıldız Deveci Bozkuş, Ankara:Atatürk Araştırma Merkezi Yay.

Kılıçdağı, Ohannes (2010). “The Armenian Community in Constantinople”. Armenian Constantinople, Ed: Richard G. Hovannisian, \& S. Payaslian. USA: Mazda Publishers.

Kırmız1, Abdülhamit (2018). "European Educational Backgrounds of Armenian Officials in the Ottoman Empire", Middle Eastern Christians and Europe: Historical Legacies and Present Challenges. Edt: Andreas Schmoller, Zurich: LIT.

Koptaş, Rober (2011). “Zohrab, Papazyan ve Pastırmacıyan'ın Kaleminden, 1914 Ermeni Reformu ile İttihadç1-Taşnak Müzakelereleri”, İmparatorluğun 
Çöküş Döneminde Osmanlı Ermenileri: Bilimsel Sorumluluk ve Demokrasi Sorunları, Yay. Haz. Fahri Aral, İstanbul: Bilgi Üniv. Yay.

Marchese, Ronald T. and Marlene R. Breu (2010). "Intersection of Society, Culture and Religion”, Armenian Constantinople, Ed: Richard G.Hovannisian, \& S. Payaslian. USA: Mazda Publishers.

McCabe, Ina Baghdiantz (2010). "The Armenian Bible of 1623" Armenian Constantinople, Ed: Richard G. Hovannisian, \& S. Payaslian, USA: Mazda Publishers.

Nichanian, Marc (1999). "Enlightenment and Historical Thought", Enlightenment and Diaspora, The Armenian and Jewish Cases. Edt: Richard G. Hovannisian and David N. Myers, Atlanta-Georgia: Scholor Press.

Oshagan, Vahé (1999). "From Enlightenment to Renaissance: The Armenian Experience", Enlightenment and Diaspora: The Armenian and Jewish Cases, Edt: Richard G. Hovannisian and David N. Atlanta, Georgia: Myers, Scholor Press.

Pamukciyan, K. (2002). Ermeni Kaynaklarından Taribe Katkılar: İstanbul Yazıları (Cilt I), İstanbul: Aras Yayınları.

Pamukciyan, Kevork (2003). Ermeni Kaynaklarından Tarihe Katkllar: Zamanlar, Mekanlar, İnsanlar (Cilt III), İstanbul: Aras Yayınları.

Panossian, Razmik (2006). The Armenians, From Kings and Priests to Merchants and Commissars, New York: Columbia University Press.

Safarian, Alexander (2007). "On the History of Turkish Feminism”, Iran and the Caucasus, (11/1):141-151.

Somel, Selçuk Akşin (2011). “Osmanlı Ermenilerinde Kültür Modernleşmesi, Cemaat Okulları ve Abdülhamid Rejimi”, İmparatorluğun Çöküş Döneminde Osmanlı Ermenileri: Bilimsel Sorumluluk ve Demokrasi Sorunları. Yay. Haz.: Fahri Aral. İstanbul: Bilgi Üniv. Yayınları.

Shirinian, Manea Erna (2010). "Armenians among the Byzantine Political Elite”, Armenian Constantinople, Edt: Richard G. Hovannisian, \& S. Payaslian. USA: Mazda Publishers.

Soysal, İ. (t.y.). Türk Devleti Hizmetinde Ermeniler, Aktüalite. Taha Toros Arşivi. Erişim tarihi ve adresi: 12.09.2019 http://earsiv.sehir.edu.tr:8080/ xmlui/bitstream/handle/11498/19966/001507722006.pdf?se 
Şahin, Gürsoy (2008). Osmanlı Devleti’nde Katolik Ermeniler Sivaslı Mikhitar ve Mıkhitaristler, İstanbul: IQ Kültür Sanat Yayınları.

Şişman, Adnan (2004). Tanzimat Döneminde Fransa’ya Gönderilen Osmanl Ögrencileri: 1839·1876, Ankara: TTK Yayınları.

Şişman, Adnan (1998). "XIX Yüzyıldan XX Yüzyıl Başlarına Kadar Avusturya’ya Gönderilen Osmanlı Ögrencileri Hakkında”, Afyon Kocatepe Sosyal Bilgiler Dergisi, Sayı (1), 11-23.

Terzi, A. T. (2001). "Osmanlı Maliyesinde Söz Sahibi Üç Ermeni Nazır: Agop, Mikail ve Ohannes Paşalar”, Uluslararası Türk Ermeni İlişkileri Sempozyumu, 24-25 Mayıs, İstabul: İstanbul Üniv. Yay.

Terziyan, Terziyan (1891). Talim-i Lisan-ı Ermeni, İstanbul: Bağdadliyan Matbaas1, $102 \mathrm{~s}$.

Thomson, Robert W.(2010). "Constantinople and Early Armenian Literature” Armenian Constantinople, Edt: R. G. Hovannisian, \& S. Payaslian, USA: Mazda Publishers.

Tok,Özen (2009). “Osmanlı İmparatorluğu'nda Millet Sisteminin Çözülmesi

Bağlamında Ermeni Millet Nizamnamesi”, Hoşgörüden Yol Ayrımına Ermeniler, 22-24.

Toprak, Zafer (1989). "Diran Kelekyan, Fransız Devrimi ve Mülkiye Mektebi”, Tarib ve Toplum, (67/7): 39-41.

Torkumyan, Kevork (1897). İpek Böceği Beslemek ve İpek Böceği Tohumu İstihsal Etmek Usûlleri, İstanbul: Düyun-1 Umumiye-i Osmaniye Varidat-1 Muhassasa İdare-i Merkeziyesi Matbaası.

Tuğlacı, Pars (2004). Tarih Boyunca Batı Ermenileri, İstanbul: Pars Yay.

Tuğlacı, P. (1992). Ermeni Edebiyatından Seçkiler, İstanbul: Cem Yayınevi.

Ülken, Hilmi Ziya (2016). Uyanış Devirlerinde Tercümenin Rolü, İstanbul: İşbankası Yay., 5.Baskı.

Vahan, Orhan (1882). Şerh-i Kanun-1 Ticaret, İstanbul: Bekir Efendi ve Mahmud Bey Matbaas1, 2. Baskı, 88 s.

Walker, Christopher J. (1980). Armenia, The Survival of a Nation. London: Croom Helm.

Yarman, A. (2001). Osmanlı Sağlık Hizmetlerinde Ermeniler ve Surp Pırgiç Ermeni Hastanesi Taribi, Çakmak, A. (Ed.). İstanbul: Surp Pırgiç Ermeni Hastanesi Vakfi. 
Yazan, Ö. (2018). “19. yy. Sonlarında Osmanlı Tarım İşletmelerinde Yönetim ve Muhasebe Uygulamaları: "Çiftlik İdaresi” Örneği”, Accounting and Financial History Research Journal, Special Issue, (09), 280-332.

Yıldırım, R. V. (2016). “Agop Handanian (1834-1899): Forensic medicine Professor in Imperial School of Medicine", Journal of Medical Biography, 24(2), 232-234.

Y1ldı, Ö. (2012). "The History of Halkalı School Of Agriculture”, International Journal of Social Science, 5(4), 323.

Zeidner, Robert F. (1976). "Britain and the Launching of the Armenian Question”, International Journal of Middle East Studies, (7/4): 465-483.

Zekiyan, Boğos Levin (2001). Ermeniler ve Modernite: Gelenek ve Yenileşmel Özgüllük ve Evrensellik Arasında Ermeni Kimliği, İstanbul: Aras Yayınları.

Zekiyan, Boghos Levin (1999). "The Armenian Way to Enlightenment: The Diaspora and Its Role", Enlightenment and Diaspora: The Armenian and Jerwish Cases. Edt: Richard G. Hovannisian and David N. Atlanta - Georgia: Myers, Scholor Press. 
